\title{
The influence of sexual dimorphism on the phe- notypical properties of poplar
}

\author{
Anatoly Tsarev
}

All-Russian Research Institute of Forest Genetics, Breeding and Biotechnology 105 Lomonosov St., Voronezh, Russia 394087, ORCID: 0000-0001-8019-0016, anatolytsa@gmail.com

\begin{abstract}
The influence of sexual dimorphism on commercial-biological traits of the most widespread poplar of the world Populus tremula L. in the Central forest-steppe of the European territory of Russia was studied. The analysis was made of the distribution of male and female clones in general, the effects of humidity, the richness of the soil, and surrounding vegetation on their productive capacity as well as core rot damage. The study presents survey results of 620 aspen plots spread out over an area of 823 hectares as well as more detailed data obtained from 3 pairs of test plots in which the indicators of male and female aspen stands were compared under identical or similar conditions. The study showed that the area of male aspen in the studied region is 4.5 times larger than that of females. The former prevail in drier and less fertile conditions while females gravitate towards more favorable growing conditions. The comparison of the productive capacity of male and female clones of the same age class, growing in identical or similar growing conditions showed that the height, diameter, and volume of the trunks were higher in male trees. Female aspen trees were less affected by core rot in the best conditions of growth, and male ones were more resistant at the worse ones.
\end{abstract}

Keywords: : aspen, sexual dimorphisms, distribution of male and female clones, productive capacity, the core rot.

\section{Introduction}

The influence of sexual dimorphism in dioecious plants has long attracted the attention of researchers to clarify the significance of this phenomenon on the growth and resistance of different sex individuals.

Various publications of the $20^{\text {th }}$ century, such as Tkachenko [1951], Danilov \& Stepanov [1958], Muhle-Larsen [1954], Eisenreich [1959], Minina [1960], Rohmeder \& Shönbach [1959], Dzhaparidze, [1963], Vikhrov et al. [1966], Volkovich [1966], and the beginning of the $21^{\text {st }}$ century, for instance A. I. Sivolapov [2005], Randryamanana [2014], Robinson et al. [2014], Yang et al. [ 2015], Li et al. [2016], Melnikova N.V et al. [2017] deal with it.

Different species in different countries and conditions have shown different results. Thus, the large sizes of male individuals are indicated in numerous studies; regarding poplars by M. E. Tkachenko [1951], C. Muhle-Larsen [1954], and H. Eisenreich [1959]; Amur cork tree Phellodendron amurense Rupr. by A. P. Nechajev [1962]; and Ash Fraxinus L. by E. Rohmeder and H. Shönbach [1959].

Recently, there has been a surge in interest in this issue of poplars. For instance, Yanni Yang et al. [2015] found that Populus cathayana they studied, males had an advantage over females in the growth and accumulation of carbohydrates, and Yan Li et al. [2016] showed that Populus deltoides males had a competitive advantage in salinity stress.

In the publication, N.V. Melnikova et al. [2017] summarizes several studies of the last decade regarding the response of different sex poplars in different conditions of growth to stressful effects such as drought, salinization, heavy metal content, nutrient deficiency, increased $\mathrm{CO}_{2}$ concentration, etc.

According to a study of the tolerance to a drought of Populus cathayana and Populus yunnanensis in the climate chamber and the greenhouse, the above publication indicates that males of these poplars more effectively adapt to moisture deficiency than females. Under conditions of stress caused by 
drought, inhibition of growth, photosynthesis, and assimilation of oxygen in female specimens is more significant than in male ones [Xu et al., 2008; Zhang et al., 2010; Chen et al., 2010; Peng et al., 2012; Han et al., 2013; Li et al., 2015 - as cited in Melnikova et al., 2017].

Researchers were also divided on the health and good shape of the trunk of males and females. Pauley [as cited in Mühle-Larsen, 1954] noted that of the 76 poplar clones selected in the populations of the USA and Canada in terms of growth strength, health, and good trunk shape, only 18 (23.7 $\%)$ were female. On the other hand, V.B. Volkovich [1966] and V.E. Vikhrov et al. [1966] found that female aspen trees are less affected by core rot than male ones.

Recently, studies of two Swedish collections of $P$. tremula did not find differences between male and female trees in height, leaf size, C / N ratio, and some other indicators [Robinson et al., 2014]. Although, like other researchers [Randryamanana, 2014], the authors believe that more research is needed for more accurate data.

The inconsistency of the results of various studies shows that this question needs additional study of specific tree species in different regions and growing conditions.

The purpose of this study was to research the effect of sexual dimorphism on the manifestation of various phenotypic characteristics of Populus tremula L., which is one of the most common naturally growing poplars in Russia and the world.

\section{Materials and Methods}

The studies were conducted in the Central Black Earth region of Russia. The source material was a survey of aspen of the right bank of the Educational Experimental Forestry of the Voronezh Forestry and Technology Institute (currently Voronezh State University of Forestry and Technologies).

The geographic coordinates of the study area are 51-52 north latitude and $39-40^{\circ}$ east longitude. The average annual precipitation is $550-560 \mathrm{~mm}$. The average annual temperature is $+4.6-+5.6^{\circ} \mathrm{C}$. The predominant type of soil varies from gray forest to chernozems (black-colored soil). The depth of the groundwater level in the territory of the examined massif is quite variable, but the comparative experiments described below were carried out under identical or similar conditions.

The examination of aspen plots was complete and selective. A complete survey of aspen trees was carried out at Educational Experimental Forestry of the Voronezh State University of Forestry and Technologies on an area of 823 hectares (620 aspen plots).

An individual profile for each plot was created where in addition to taxational specifications of growing stock we included data on the sex of aspen clones, relief, soil, phenophase, defectiveness, bark type, branching, straightness of the trunk and existence of dry boughs.

Laying out the test plots was carried out according to the methodology generally accepted in research work with a complete enumeration of trees and noting the category of trunk quality, tree damage, growth class, sex, etc. In this case, the quality category of trunks was evaluated on a 3-point scale: 1) the trunk is straight from base to top; 2 ) the trunk is medium curved - straight from the base to the beginning of the crown, and in the crown it is curved; 3 ) the trunk is curved before the beginning of the crown.

Each test plot was described in detail including relief, soil, ground cover, undergrowth, and other characteristics.

The trees in three test plots were color-coded according to sex during flowering.

For a general assessment of the growing conditions, the Alekseev-Pogrebnyak taxonomy was used [Pogrebnyak, 1955].

To ensure the correct classification of trees as healthy on each trial plot, 20-30 trees were drilled with a growth drill.

At 17 sample plots, 3 reference trees were cut down and data on habitual-morphological and biological (sex, phenoform, etc.) features of the samples were recorded on specially designed cards.

When describing reference trees, in addition to the usual data, the core diameter, and rot, if present, were measured in the middle of two-meter segments.

As noted above, sexual dimorphism externally can manifest itself (or not manifest) in various morphological and other biological features. Of the many features by which male aspen clones may differ, several of the most economically important ones were selected such as straightness of the trunk, crown power, clearing of branches, productive capacity indicators. All characteristics were taken into account for aspens over 30 years old. To process the results of diameter measurements, standard statistical methods were used [Snedecor, 1961].

\section{Research Results and Discussion}

\section{The sex ratio and distribution of male and female} aspen trees, depending on the conditions of growth.

Of the surveyed 620 plots on an area of 823 hectares of aspen trees the area of the forest stand with a predominance of male trees was 489 hectares, while a predominance of female trees 108 hectares. On an area of 226 hectares, the aspen trees turned out to be non-blooming or with affected flowers. Thus, the ratio of female to male trees in the area was expressed as 1:4.5.

These results show a deviation from the genotypic formula, according to which in the offspring of dioecious organisms the sex ratio should be defined as 1: 1. The offset on the one hand seems rather unusual but on the other hand, it cannot be called unique. At one point E.G. Minina [1960] noted that "Gender in plants is expressed in diverse forms, it is not sufficiently resistant to external influences and can shift in more or less significant sizes depending on the strength of the effects of various factors and the degree of liability of the organism itself." These provisions are also established by A.A. Shakhov [1956], who found that on saline soils in most cases male individuals of dioecious species 
of tree species (aspen, poplar, willow) predominate. Conversely, in non-saline or slightly saline areas, female individuals predominate to a large extent (up to $80 \%$ ).

M. Kolelishvili [1937] and G. Rodionenko [1945] noted that in arid regions the number of female Ficus carica $L$ and Populus diversifolia Schrenk is greatly reduced. It increases only with improved water supply. In the dry conditions of southern Armenia, the sex ratio of Pistacia L. shifts in favor of males 9 times, that is, the sex ratio is 1: 9 [A.V. Ivanova, 1949].

It is possible that the moisture content of the growing conditions likewise affects the distribution of male and female aspen species. This is also evidenced by some published facts. Paul Reim [Reim, 1930] in Finland and Estonia found the sex ratio of aspen as 1: 2, and V. B. Volkovich [1966] in the Leningrad Region 1: 1.9 in favor of the male. Given the greater moisture supply in these areas, compared with the Voronezh Region, it can be assumed that a much sharper predominance of forest stands with male aspen trees in the massif we studied (4.5: 1) may be due to greater aridity of the examined area. At the same time, male trees are probably more xerophytic than female ones. This is confirmed by the data compiled from a study of 220.8 hectares of male and 44 hectares of female aspen clones in the next diagram (Figure 1).

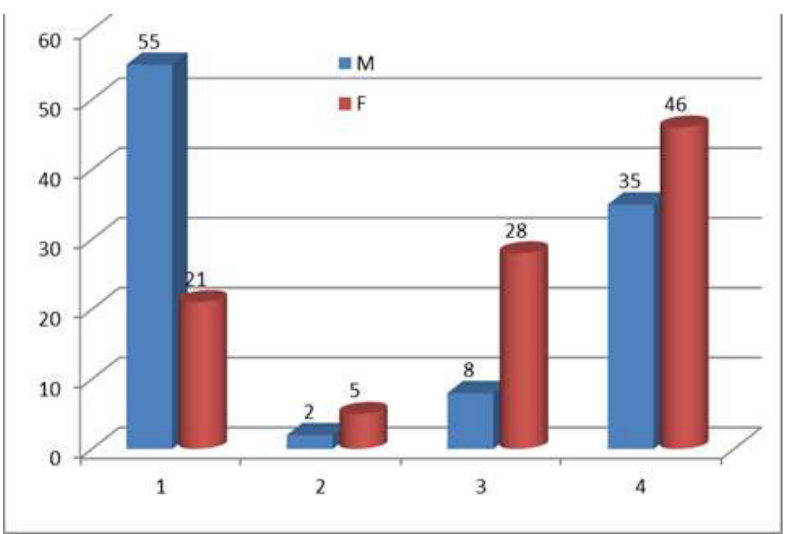

Figure 1

Distribution of male (M) and female (F) aspens on positive and negative relief elements, in percent of the area: 1 - watershed slopes; 2 - saucer-shaped depressions; 3 - ravines; 4 - lower parts of the slopes.

From the data in Figure 1, it can be seen that $79.5 \%$ of female aspens are located on the lower, more moistened elements of the relief (the lower parts of the slopes, ravines, and saucer-shaped depressions) and only $20.5 \%$ of them are confined to the higher, drier locations (tops and upper parts of slopes). In male aspen, these indicators amounted to 45.3 and $54.8 \%$. That is, they have a higher tolerance to the lack of moisture.

Female aspen trees were also more demanding for soil fertility. The study of forest stand with male clones on an area of 470.4 hectares and female clones on an area of 106.8 hectaresconfirmed this hypothesis (Figure 2).

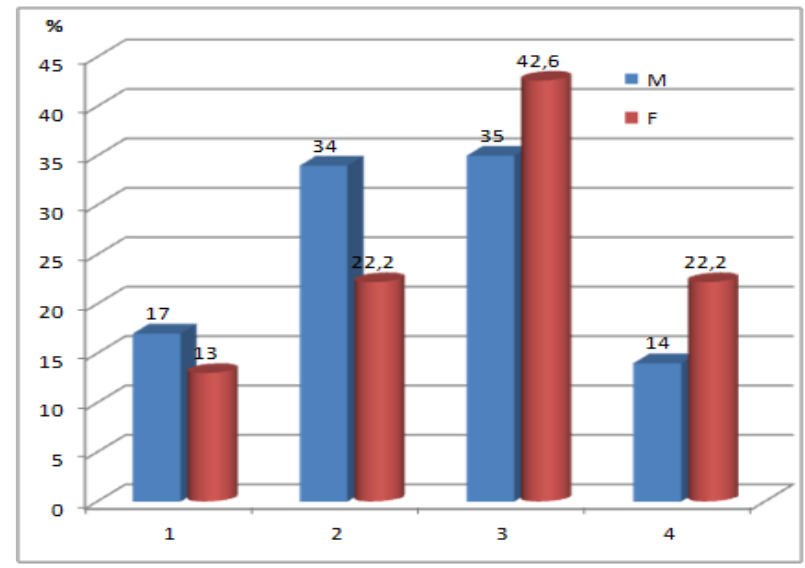

Figure 2

Distribution of the area of male (M) and female (F) aspen trees by soil differences, in \% of the surveyed areas: 1 - sandy soils; 2 - light gray and gray sandy loam; 3 - dark gray sandy loam; 4 - loamy soils.

As can be seen from the data in the diagram in Figure 2, male clones predominate on poorer soil differences (sandy, light gray, and gray sandy loams), and female clones predominate on the richer (dark gray sandy loam and clay-loam). Thus, the predominance of male aspen trees over female in the studied forest stands, expressed in the ratio of $4.5: 1$, is apparently due to their greater xerophytism and ability to put up with more adverse soil conditions.

\section{Habitual-morphological characteristics and} productive capacity of male and female aspen trees

A survey of 402.5 hectares of male aspen clones and 91.6 hectares of female clones showed that the trunk shape is somewhat better in male aspen trees: the average percentage of straight and medium-curved trunks was $75.3 \%$, and curved was $24.7 \%$. In female aspens, these indicators were $67.1 \%$ and $32.9 \%$ respectively.

Regarding the purity of trunks from knots, no differences depending on gender were found: the size of the knotless part of the trunk in male aspen trees was on average $21.4 \%$, and in female $-21.7 \%$ of the total height of the trees.

In order to make judgments about the productive capacity of male and female aspen trees under the same growing conditions, 5 test plots (TP) were laid out in type $C_{2}$ forest. Whereas one of them, with an area of 0.6 hectares (TP 11), was laid out directly at the junction of male and female clones of aspen, so male and female specimens were presented in it under identical conditions. Four others were laid out, although not nearby, but under the same conditions. Two in male aspen (TP $20-0.25$ hectares and TP $34-0.15$ hectares) and two in female aspen (TP $10-0.25$ hectares and TP $33-0.15$ hectares) (Table 1). 
Table 1

Taxation specifications of different sex aspen trees

\begin{tabular}{|c|c|c|c|c|c|c|c|c|c|}
\hline \multirow{2}{*}{$\begin{array}{l}\text { №№ } \\
\text { comparable } \\
\text { pairs of TP. }\end{array}$} & \multirow[t]{2}{*}{$\begin{array}{l}\text { №№ } \\
\text { TP. }\end{array}$} & \multirow[t]{2}{*}{ Gender } & \multirow[t]{2}{*}{ Age, years } & \multirow[t]{2}{*}{ Normality } & \multirow[t]{2}{*}{$\begin{array}{l}\text { Average } \\
\text { height, } m\end{array}$} & \multirow[t]{2}{*}{$\begin{array}{c}\text { Average } \\
\text { diameter, } \mathrm{cm}\end{array}$} & \multirow{2}{*}{$\begin{array}{l}\text { Average } \\
\text { volume of } \\
\text { trees, } \mathrm{m}^{3}\end{array}$} & \multicolumn{2}{|c|}{$\begin{array}{c}\text { Advantage of } \\
\delta \text { aspens }\end{array}$} \\
\hline & & & & & & & & $\begin{array}{l}\text { By height, m/ } \\
\text { diameter, cm }\end{array}$ & $\begin{array}{l}\text { By trunk volume, } \\
\text { m3 / \% }\end{array}$ \\
\hline \multirow[t]{2}{*}{ I } & 11 & $\hat{0}$ & 42 & 0.70 & 20.9 & 21.8 & 0.304 & $+0.3 /+1.6$ & $+0.047 / 18.3$ \\
\hline & 11 & q & 42 & 0.70 & 20.6 & 20.2 & 0.257 & & \\
\hline \multirow[t]{2}{*}{ II } & 34 & $\hat{0}$ & 39 & 0.82 & 20.4 & 21.3 & 0.283 & $+1.5 /+1.7$ & $+0.061 / 27.5$ \\
\hline & 33 & ㅇ & 39 & 0.81 & 18.9 & 19.6 & 0.222 & & \\
\hline \multirow{2}{*}{ III } & 20 & $\hat{0}$ & 44 & 0.97 & 21.3 & 21.2 & 0.293 & $+0.9 / 0$ & $+0.012 / 4.3$ \\
\hline & 10 & 우 & 43 & 0.60 & 20.4 & 21.2 & 0.281 & & \\
\hline
\end{tabular}

According to data in Table 1, it is clear that the height superiority was observed for male aspen trees in all cases, and in terms of diameter, male aspen was superior in two of three samples. In the third pair, there seems to be no advantage in diameter, but it is necessary to take into account the lower density of the female area crop. This undoubtedly contributed to an increase in the average diameter of aspen in the TP dominated by female trees. However, even in this case, it did not exceed the average diameter of the male stand.

The difference in diameter for the first two pairs was estimated by a statistical method (Table 2). authors who established higher productive capacity of males compared to females in the same growing conditions.

\section{Prevalence of core rot in female and male aspen stands}

A survey in the Voronezh Region of male aspen clones on an area of 402.1 hectares and female clones on an area of 91.6 hectares showed that overall core rot was less among female aspen trees than the male by $33 \%$. Verification of these data

Table 2

Indicators of statistical processing of the diameter values

\begin{tabular}{|c|c|c|c|c|c|c|c|}
\hline $\begin{array}{l}\text { №№ compa- } \\
\text { rable pairs } \\
\text { of TP. }\end{array}$ & $\begin{array}{l}\text { №№ } \\
\text { TP. }\end{array}$ & Gender & $\begin{array}{l}\text { Average diameter, } \\
\qquad \mathrm{D} \pm m, \mathrm{~cm}\end{array}$ & $\begin{array}{l}\text { Standard deviation, } \\
\pm \sigma, \mathrm{cm}\end{array}$ & $\begin{array}{c}\text { Variation } \\
\text { coefficient, V, \% }\end{array}$ & $\begin{array}{c}\text { Experiment exactness, } \\
\qquad \mathrm{P}, \%\end{array}$ & $\begin{array}{c}\text { Accurateness of the } \\
\text { differences, } t\end{array}$ \\
\hline \multirow[t]{2}{*}{ I } & 11 & $\hat{o}$ & $21.8 \pm 0.35$ & 3.5 & 16.0 & 1.6 & 3.8 \\
\hline & 11 & 우 & $20.2 \pm 0.24$ & 2.6 & 12.9 & 1.2 & \\
\hline \multirow[t]{2}{*}{ ॥ } & 34 & $\hat{0}$ & $21.3 \pm 0.68$ & 4.6 & 21.7 & 3.2 & 2.3 \\
\hline & 33 & 우 & $19.6 \pm 0.33$ & 2.8 & 14.3 & 1.7 & \\
\hline
\end{tabular}

As can be seen from the data in Table 2, differences in growth in diameter between male and female aspen trees are quite significant.

Trunk volumes in all three compared pairs of test plots were higher in male aspens (Table 1).

The data (Tables 1 and 2) does not confirm the conclusions of V.B. Volkovich [1966] and V.E. Vikhrova et al. [1966]. These data are also inconsistent with the findings of two aspen collections in Sweden [Robinson et al., 2014].

Conversely, they are consistent with data for poplars of S. Pauley [as cited in Muhle-Larsen, 1954], M.E. Tkachenko [1951], O. Shrök [as cited in H. Eisenreich, 1959], F. L. Shchepotieva [1959], Yanni Yang et al. [2015], Yan Li et al. [2016] and other was carried out on aspen trees of one age class (fifth: 41-50 years) on an area of 267.2 hectares. The number of trees with the presence of core rot here among male aspen trees was 33.7 $\%$ and among female $22.2 \%$. In other words, female aspen trees were 1.5 times less affected. An analysis of the location conditions data (Figure 3) showed that such an advantage is observed in favorable conditions of location $\left(B_{3^{\prime}}, C_{2}, C_{3^{\prime}}, D_{2}, D_{3}\right)$ that were more fertile and humid. 


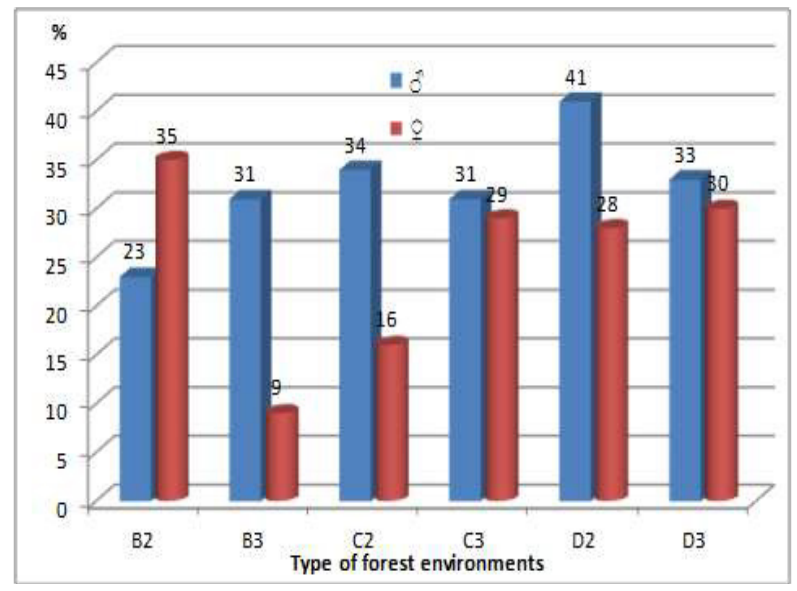

Figure 3

The prevalence of core rot (\% of affected trees) in male and female aspens over the age of 30 years in various conditions of growth.

In unfavorable conditions for aspen growth $\left(B_{2}\right)$ male clones of aspen were more resistant.

\section{Summary}

1. Studies of aspen in the Central Black Soil of European Russia have confirmed the hypothesis that the ratio of males and females in bisexual plants is associated with the conditions of their growth.

2. Surveys of large arrays of aspen showed that in drier and less favorable conditions, male plants predominate, and in more humid and favorable conditions, female plants prevail.

3. A comparison of the productive capacity of male and female stands growing under identical or similar conditions of growth showed that the height, diameter, and volume of the trunks were higher in male trees.

4. A study of core rot prevalence showed that, in general, female trees were less affected by this pathogen. But the study of rot damage, depending on the conditions of habitat showed that under favorable conditions, female trees are less affected, and under less favorable conditions, male trees.

5. Following the established patterns in artificial afforestation can significantly increase the productive capacity and sustainability of created stands.

\section{Acknowledgements}

The author would like to thank Georg von Wueglish, Anton Pertsevoi and Marina Kulinich for their help in English editing manuscript.

\section{References}

Danilov MD, Stepanov VS (1958) Morphological and physiological features of male and female individuals of balsamic poplar // Forestry. No 6. - (In Russian). Dzhaparidze LI (1963) Gender in plants. Part 1. Tbilisi: Publishing House of Georgia SSR Science Academy. - 308 p. - (In Russian).

Eisenreich H (1959) Fast-Growing tree species. Moscow: Publishing House of Foreign Literature. - 508 p. - (In Russian).

Ivanova AV (1949) To the question of the resumption of Pistacia in Armenia // Reports of Armenian SSR Science Academy, vol. 10. - P. 125-128. - (In Russian).

Kolelishvili M (1937) to Master the Turkmen figs // Soviet subtropics, № 12. - (In Russian).

Li Y, Duan B, Chen J, Korpelainen H, Niinemets Ü, Li C (2016) Males exhibit competitive advantages over females of Populus deltoides under salinity stress // Tree Physiology, Volume 36, Issue 12, 1 December 2016, P. 1573-1584, https://doi.org/10.1093/treephys/tpw070.

Melnikova NV, Borkhert EV, Snezhkina AV, Kudryavtseva AV, Dmitriev AA (2017) Sex-Specific Response to Stress in Populus. Frontiers in Plant Science; 8:1827. Published online 2017 Oct 26. https://doi.org/10.3389/fpls.2017.01827.

Minina EG (1960) Sex determination in forest woody plants (wood sexualization). Proceedings of Forest Institute of the USSR Science Academy. Vol. 47. - 76-163. - (In Russian).

Muhle-Larsen C (1954) Du repport entre le sexe et le development chez les arbres dioiques // Rapp. et communs. Huitième Congr. Internat. Bot., Sec. 13. Paris. - p. 25-26.

Nechaev AP (1962) Sexual dimorphism in the trees is the Amur cork tree (Phellodendron amurense Rupr.) // Moscow: Bulletin of MOIP, Department of biology. No. 2. - (In Russian).

Pogrebnyak PS (1955) Fundamentals of forest typology. Kiev: Publishing House of the Ukrainian SSR Academy of Sciences. - 456 p. - (In Russian).

Randryamanana T (2014) Global change and sexual dimorphism in two Salicaceous species - Case of Populus tremula L. and Salix mirsinifolia Salisb. Dissertation in Forestry and Natural Sciences No 155. Joensuu, Finland: University of Eastern Finland.-53p.

Reim P. (1930) Haava paljunemis - bioloogia // Ülikooli oppemetskonna väljaane (Die Vermehrhrungsbiologie der Aspe // Mittailungen der Forstwissenshftliche Abteilung der Universität). Tartu, No 16. S. I-XVI. (In Estonian).

Robinson KM, Delhomme N, Mähler N, Schiffthaler B, Önskog J, Albrectsen BR, Ingvarsson PK, Hvidsten TK, Jansson S, Street NR (2014) Populus tremula (European aspen) shows no evidence of sexual dimorphism. BMC Plant Biology:276. Published: 16 October 2014. $-29 \mathrm{p}$. http://doi.org/10.1186/s12870-014-0276-5.

Rodionenko GI(1945) Biological characteristics of the Asiatic poplar (Populus diversifolia Schrenk.). Soviet botany, № 6. P. 35-40. - (In Russian).

Rohmeder E, Schönbach H (1959) Genetik und Züchtung der Waldbäume. Hamburg und Berlin: Verlag Paul Parey. - $338 \mathrm{~S}$. https://doi.org/10.1002/bimj.19650070328

Shakhov AA (1956) Salt stability of plants. Moscow: Science Publishing House. 552 p. - (In Russian).

Sivolapov Al (2005) Gray poplar: genetics, breeding, reproduction. Voronezh: Voronezh State University. - 157 p. - (In Russian).

Tkachenko ME (1951) the Materials of the steppe afforestation. Moscow-Leningrad: Goslesbumizdat. 84 p. - (In Russian).

Vikhrov VS, Fedorov N, Kochanovsky SB (1966) On the stability of aspen to heart rot // Ways to improve forest productivity / Proceeding All-Union meeting on forest productivity / ed. Vikhrov V. E. Minsk: the highest school. - P. 233245. - (In Russian).

Volkovich VB (1966) On the ratio of male and female clones and aspen trees in the forests of the Leningrad region // proceedings of higher educational institutions. Forest journal. No 2. - P. 22-24. - (In Russian).

Yang $Y$, Jiang H, Wang M, Korpelainen H (2015) Male poplars have a stronger ability to balance growth and carbohydrate accumulation than do females in response to a short term potassium deficiency. Physiologia Plantarum, January 2015. No 155 (4). https://doi.org/10.1111/ppl.12325 